\title{
On the Practical Significance of All-around Activated Teaching Method
}

\author{
Gong Yun Xin \\ Wuxi College of Science and Technology \\ Wuxi, 214028,China \\ e-mail:gongyunxin@sina.com
}

Keywords: Overall Activation ;Personal System ;Tacit Knowledge

\begin{abstract}
This article comprehensively expounds the problems existing in China's education, and discusses the direction of the reform of education: it should be pluralistic establishment, management and evaluation of the school. Final school forms should be pluralistic ones in terms of majors, teaching material, teaching methods, faculty, teaching plan, teaching test and entrance channels
\end{abstract}

Five thousand years of the Chinese nation has created a brilliant civilization. The extensive and profound Chinese culture has been leading the world cultural trend. In modern times, the country has fallen behind the west in science and technology. The first and the second industrial revolution left China completely behind because of the long-term isolation and little knowledge of the outside world. The invasion of the westerners made Chinese people see the world.

Learning about the rapid development of the world and the backwardness of the Chinese nation, many pioneers, holding the grand ideal of the national revitalization, went abroad to study to explore the renewal of the Chinese nation. Especially revolutionists and statesmen led by Dr. Sun Yat-sen defined renewal as a political revolution, the western democracy, which was introduced to China, namely the three people's principles of the republic of China, finally turning a one-party rule of the country. Meanwhile emerged the international communist movement, Marxism-Leninism, s Revolutionaries headed by Mao Zedong who established the People's Republic of China in China in a more radical way, the vision is to establish the multi-party cooperative system of democracy, but it soon deviated from the original intention. Why cannot democracy dream come true?

The author thinks that is because the introduction of advanced regime doesn't go hand in hand with the introduction of advanced education, citizens in the country don't receive a comprehensive ideological education. According to the common sense people of the same kind will have the same kind of government and country. And the Chinese nation for thousands of years worships authoritarian power and servility, always dreams of a wise monarch, sage emperor to benefit the people. Citizen consciousness is not strong. They don't think of performing their duties first and do something for others and for social change.

How can a democratic regime be established under such a national quality? Who has a bit of democracy consciousness among the people around you? All ranks of the leading officials are the same. Nobody thinks of separation of powers, nobody thinks of power balance. Everyone seeks power and benefit and plays politics to the extreme. There is no democratic state without democratic citizens; there is no democratic citizen without democratic education.

Second, the education method of agricultural era has not been changed into the education method of the era of industrialization and informatization (digital). If our leaders and our college or school teachers are asked what education method of the era of industrialization and informatization is, how many of them can answer? For thousands of years a teacher-centered, one-way education mode has been used. National industrialization and informatization is based on the industrialization and informatization on the part of its people.

Through nearly a hundred years' exploration practice, the final state reconstruction is also a failure; industrialization also is fake, hence no world-class scientists, entrepreneurs, inventors, writers and artists. All this should lead to everyone's deep thought. Thirdly, education thought of Confucius has been passed down for over two thousand years, why hasn't it cultivated the national citizens well? It would be a lucky thing even if it has brought forth a few of the saints and great 
persons. But on the contrary, the history of the Chinese nation is almost warfare,

In every dynasty, that kind of damage and the kind of bloody cruelty is beyond description. And even now still there cannot be peaceful transfer of power, whenever there is a transfer; there will be a certain group of people suffering confinement or crackdown. How many countries around the world are still so backward? Will these not be enough to cause the vigilance and reflection of our nation? How can those who seek power and benefit face their own ancestors in the face of the Chinese civilization of five thousand years? Fourthly, there is no reflection and change of the education system. Student-orientedness is the essence of the education, education in China is not for human education, development, but serves as a political tool throughout history. This system can only cultivate tools and nerds, but nobody has ever thought that something has gone wrong with the education system rather than with personal matters.

For nearly a century of educational history, China does not have its own education method, nor its own educators, At the earliest was the introduction of western education thoughts, then the comprehensive copy of the Soviet education system after 1949, And all was incomplete and broken, the European and American countries attaches great importance to family education, For example, Edison didn't go to school, his whole education was offered by his mother. After that, family education occupies very important position in the western world, Italy early childhood education expert Montessori founded "children's home" across Europe and the United States.

Europe and the United States pay special attention to family education, each family has piles of toys, their home equipment types are better than those in the best kindergartens of our country, because the early European industrial system was based on the family as the basic unit. Specialization, modular organization of production was conducted at home, the children witnessed the whole process of industrial creation, product development, product production and dissolution, and this long-term edification of children in this environment laid a solid foundation for inventions and at the same time established their collective spirit and cooperation spirit.

America admits home schooling. Home schools, public schools, private schools have the same treatment. All kinds of units in the European and American countries pay special attention to education, social education attaches great importance to the social practice, Especially, German legislation enforces enterprises to open to school, to cultivate the students as their social responsibility. Every community with 100000 people in the United States has two community colleges. Society, families, schools form an organic system of education, making comprehensive and high quality talent training. Can the only introduction of their classroom teaching be perfect? European and American classroom teaching is very rich, knowledge learning and skill practice, extracurricular activities, organic combination form a perfect education process.

At best, only a third of their class teaching system is introduced into our country. Schools in China shoulder the whole function of education shared by the school, family and society in Europe and the United States. This is a very important subject to study. Long-term studies have found that some abilities such as emotional quotient, professional quotient etc can not be trained only by relying on the school.

Nowadays most of the students don't want to use their mind, they hate learning. When it comes to a comprehensive practice project, they don't know how to do. Even under the guidance of their teacher, they act exactly like a puppet (part of the graduate students also are the same). When they face the new environment of the society, they are completely like "nerds".

Why does this phenomenon appear? Investigating the cause, the problem lies in the national education system and structure. The conception of education for political utility is too strong. Strong army force for the country, science for the country, education for the country, the anti-Japanese war for the defense of the country. All this conception of the political utilitarianism of education was branded deep in the heart of every Chinese. For one hundred of years, the political utilitarianism education has been strengthened again and again, ignoring the cultivation of humanity. A sound person is impossible to have a good emotional world and also impossible to abide by the proper code of conduct.

Our state has national education policy and code of conduct, but our students are still in such a 
situation, which should lead to our thinking. All of us know that there are no convention rules and behavior standards in children's mind, these rules for children are largely invisible and also are not easy to practice. Code of conduct is formed in the process of failure, misery and sufferance of losses. No activity is equal to no education for children. Implementation of code of conduct is in the activities, children don't know how to get along with others without group activities after they have grown up, and even feel hard to have a happy married life.

For an individual, the author puts forward a "for everyone's happiness in life" concept, including you, parents, and all the people around. Your happiness should also be the happiness of everyone around. Your word and deed should do no harm to yourselves, others and the society. Based on this criterion, every deed of yours should bring happiness to others. You should give others what you yourself want: love, wealth and pleasure. You must create wealth first for others and then for your own, that is to say, you must first satisfy. The joy and happiness for everyone should be your power source. Insist on what was mentioned above for a long time and you can cultivate and improve the first-class talents. Good thought decides good behavior.

Too much explicit knowledge is instilled in the process of teaching, tacit knowledge is missing.

Explicit knowledge is expressed by means of words, language or symbols. When schools provide education of only the book knowledge learning or indirect experience learning, students can't see the complete production process of how the knowledge was originally found, and can't see the knowledge creator's process of thought of intuition and imagination, observation and experiment, reflection and reasoning. Therefore students can only learn to possess knowledge, consume knowledge but they don't know how to make knowledge. In addition, this kind of indirect forms of knowledge learning makes students hard to generate enough impetus, active imagination, which leads to their lack of the necessary tacit knowledge.

Tacit knowledge is essentially a kind of comprehension, and a kind of ability of understanding, mastering, restructuring and efficiently using experience. Lack of tacit knowledge, their knowledge combination capacity, regeneration ability and innovation ability are poor. In the process of success, the role of tacit knowledge is much greater than explicit knowledge. Therefore, both ability cultivation and development of creativity should start from tacit knowledge, and tacit knowledge accumulation, combination, conversion are based on participating in comprehensive practical activities as the prerequisite. So before the age of 13 , the students should be given freedom and should be guided to free creation, free development and aiming high enough to participate in world competition.

Look at Europe and the United States, America will lead the world science and technology of 20 to 50 years as their national policy and create a good environment to attract the world first-class talents to work for them. The United States has long completed a modern education system of pluralistic establishment, management and evaluation of the school. The main benefit of this system is a healthy competition and a long-term vitality.

The education in our country is rigid, the whole nation shares one kind of textbook, one leader, one sort of test (there are 2 provinces that set their own test paper but also the same model). How can this system bring forth the first-class talents? Most importantly, the country has no plan to cultivate the children before the age of six, our country hasn't established preschool education system. The education of this stage hasn't been paid attention to by most parents; this is one of the real reasons why China's education has fallen behind.

The unification of compulsory education has delayed the critical period of talent cultivation. There is a saying "the childhood is critical to the whole life", which shows importance of the child's education. But in our country this key education period is missing, long-term study shows the most critical period of IQ, EQ and MQ cultivation is before the age of 13, once the personality is formed, it is very difficult to change. We can imagine how difficult for college students who have been infected with bad habits to correct them in three or four college years. Creativity and imagination are developed in childhood.

Years of education reform has not shaken the fundamental system and structure, just making some facial changes in terms of teaching materials, teaching methods, which is not the key point. 
Therefore, the author puts forward the Universal Active Education Method; the method can be summarized into two systems, a shaft education age, called the barbell theory. (See the All-round Activation of Education Research)

The education is essentially the agricultural education system passed down thousands of years in our country; this inheritance is fit for the liberal arts talent cultivation and the theoretical engineering talent cultivation. Now we have come into the era of industrialization and informatization, but our country has not developed an education system that is suitable for industrialization and informatization training needed in national creative talent training education system. Our country's industrialization time is too short, it can be said that our national industrialization and informatization are in simultaneous progress, which is a complete "leapfrog" without the experience of technical innovation and process innovation and without the early industrial development in the process of training the talents suitable for the industrialization and the information society.

The young people growing up in the digital environment are accustomed to playing with the mobile phone, Internet, short message, interactive media, Facebook, watching TV, movies, animation stories. These media have greatly affected their brain development and also affected the way they think and learn. They don't like broadcasting, force-feeding teaching way, they like the step-by-step style and interactive, asynchronous, multitasking and collaborative learning. But the school does not take corresponding measures, but still continues to use the old mode of education, causing students to be uncomfortable and then, as time passes, dislike learning.

Now our leaders reduce the number of text books and the schooling time as a way to reform education, it is no solution to the problem of Chinese education. The crux lies in the college entrance examination policy. The author thinks it is because there are no plenty of levels of place for activities, lab and training room, laboratory, workshop, designing room. The students idle about, watch TV or play games after class. Still some students have to continue to study with a tutor coaching them at home. They have no time for autonomous learning.

The biggest problem lies in the school authorities. Mr. Qian Zhongshu once said: "In higher education, first-class teachers do research; second-grade teachers make teaching, third-grade teachers are appointed to leadership”. There is still no change. Those who know nothing about education come into the leadership through illicit channels, thus turning the school into officialdom, an arena for playing politics, seeking pleasure in managing teachers. In school politics is more important than scholarship. Teachers' pay is linked to their performance and students' achievement. The leaders have the final say in teachers' evaluation, promotion, project declaration, application for various rewards. Various methods are employed to retaliate against those who have different opinions. As a result, teachers have no independent personality, no freedom of thought. Imagine how teachers can teach students with scientific spirit.

The economic crisis in 2008 brought the world into economic collapse, and the veteran capitalist society faced comprehensive economic problems, this led everyone to full reflection to the social system, economic system and political system of capitalist countries and to the root of the economic crisis. There is a big difference between eastern and western culture, the latter advocates individualism while the former advocates collectivism, the democracy - voting system. Westerners put the leadership into the cage, it's a pity that there is no way to cage personal voting right. You can imagine a selfish group of citizens can make a good state voting system go astray. In the end, people of some kind have the same kind of state system, and the cultivation of people depends on education. The history now offers a good opportunity for our national development. The conception of Chinese educational philosophy, self-denial devotion, industriousness and thriftiness is deeply rooted in the hearts of the people. As long as we improve the existing education system in terms of technology application, industrial technology, industrial design, invention and innovation, we will be able to build a world-class education.

The premise of the realization of communism is: maximum flow of wealth, no resource crisis and everyone is equal. No resource crisis means elimination of root cause of war and then no countries. Most people are selfless, sage with utter devotion to equality, fraternity, sharing 
prosperity and eliminating class.

Possible ways to solve the problem of resources crisis are: (1) energy: thermal nuclear fusion, solar energy, biological energy; (2) food: hybrid rice, transgenic food; (3) nuclear structure: the only thing that can solve the problem of the world is to be only the nucleus structure, which, like chemical products, can synthesize all kinds of plants and animals; (4) flora: hundreds of thousands of kinds of bacteria are found anywhere in the world now, bacterial population will gradually form a base for future human various necessary elements and can be used to make fuel, food, and even building bricks and concrete, bacteria can also solve the problem of human energy to generate electricity;

The possible ways to solve the problem of equality are: (1) all need not to do heavy, dirty work, which is done by machinery. All the work is fully automated, agricultural mechanization is realized. Everyone is relaxed and happy at work after full automation. Everyone can enjoy happy work and happy life; (2) everybody is invincible, extraordinary, highly motivated a selfless saint; (3) any job can provide equal competition opportunities, and everyone is equal in jobs and job positions.

All these depend on the highly developed science and technology, and on the cultivation of high-quality talents, all the realization of the dream boils down to highly developed education. Chinese nation enjoys extraordinary intelligence and the essence of thousands of years of education. As long as our education structure is radically reformed with absorption of useful educational experience of Chinese history and foreign countries, China will be able to come to the top of the advanced education and take the future of the world. The so-called modern national education system lies in the pluralistic establishment, management and evaluation of the school. Final school forms are: diversity, pluralism, diversity of teaching material and teaching methods, teachers' pluralism, diverse teaching tests, multiple entrance channels. Students have many hobbies abilities and are proficient in liberal arts and science with political integrity.

The development direction of current education is to strengthen the ability training, form various kinds of activity rooms, laboratories, training rooms to create a cultivation environment for industrialization and informatization knowledge with the trinity of family, society, school. The urgent task now is to cancel the division of liberal arts and science. Experiment skills and comprehensive design ability test are added to the college entrance examination, thus leading the teaching to practical ability cultivation. Promote small class teaching. Strengthen creative thinking training and develop fast and efficient learning ability, agile rigorous thinking ability, and superior innovation ability, pay attention to the multiple intelligence development, and at the same time strengthen the cultivation of non-intelligence ability, activate people's universal ability, build a favorable education system for eccentric and partial individuals to develop themselves. Form an education system suitable for industrialization, informatization, cultivate first-class talents, and then the great rejuvenation of the Chinese nation is just around the corner.

\section{References}

[1] Dry springs. holographic management and success quotient [J]. Beijing: China academy of management review, 2008 (9).

[2] Shangguan Zimu. Reflection: Chinese become barrier [M]. Beijing: Beijing university of aeronautics and astronautics press, 2008. 34 and 38. 28 to 31.

[3] Shangguan Zimu. Reflection: Chinese become barrier [M]. Beijing: Beijing university of aeronautics and astronautics press, 2008. 34 and 38. 28 to 31.

[4] Yang Chengshuang. The importance of non-intelligence factors in talent training [J]. Journal of Taiyuan, Shanxi coal management cadre institute, 2004 (4).

[5] Liu Jinhua. Children's psychology development [M]. Shanghai: east China normal university press, 2008.43-4 